\title{
Value Network and Conscious Competition: A Case Study of Sugar Industry in India
}

\section{Prof.C R Rajan}

Associate Faculty, Great Lakes Institute of Management, Dr. Bala V Balachandar Campus, ECR Road, Manamai, Tirukazhukundram Taluk, Kanchipuram District, Tamilnadu - 603 102. India. Email: Office: rajan.cr@greatlakes.edu.in \& Personal: rajan.cr@gmail.com

\section{Prof. N Chandrasekaran}

Doi:10.5901/mjss.2015.v6n1p479

\author{
Adjunct Faculty, Loyola Institute of Business Administration, Chennai 600034
}

Email: Chandrasekaran@liba.edu

\begin{abstract}
In an increasingly competitive business conditions, companies need to leverage competencies of an entire business network in order to achieve competitive advantage. Supply chain network envisages how a focal firm could build a network of partners in fulfilling a customer demand. In this process, a focal firm leads and ensures fair play of role, responsibility, reward and risk sharing among all its partners. Bringing in business ecosystem configuration, one can relate how structural features of an industry and regulatory can impact the performance of the industry. In modern new generation, technology led and market oriented businesses, market forces help to align entities and focal firm commands hierarchy in both upstream and downstream towards common goal. If any of the partners find, the goal or reward and risk being unduly burdened, partner would opt out. However, there are certain traditional industries which have survived long under regulatory conditions because of its weak structuring, have focal firms burdened with conflicting objectives of partners. One such industry is that of manufacture of sugar in India which is being deregulated. However, current set of deregulatory measures are more focused on downstream linkages rather than upstream linkages. In this paper, author reviews different works connected with supply network and relates to Indian sugar industry in the context of structure and regulatory framework.
\end{abstract}

Keywords: Business ecosystem; Value creation; Supply Chain; Value Network; Structure and competitiveness; Value sharing; Sugar Industry.

\section{Introduction}

Over the last fifteen years, management literature has seen a number of works on value network, synchronized supply chain and conscious competition as themes which can work for sustaining growth of companies. All these nomenclature describes creating and sharing value among network of players. More commonly value network are believed to be working in technology sector, Hi-tech industries, telecommunications, banking and financial services, health care and so on. It may be noted here that a value chain concept propounded by Michael E.Porter (1985) has been widely used for analysis and strategy decision making in manufacturing and traditional businesses. Though Value chain as a tool focuses on value creating activity internal to the business, Porter has articulated how value chain of a firm can connect with value chain of a supplier and customer and create a value across network. The conceptual link between value system and value network needs to be deployed for strategic decision making. There is a linkage between value network and firms role agents in explaining the conduct and performance of the firm in an industry. In the following paragraph the definition of supply chain, value network and conscious competition are given to make it contextual to the paper.

Supply chain is defined as "... network of organizations that are involved, through upstream and downstream linkages, in the different processes and activities that produce value in the form of products and services in the hands of the ultimate customer" (Christopher 1998). We could infer that there is a nodal firm which offers a product or service to ultimate customers at a price which is inclusive of supply chain profits. Profits are shared across the network based on roles, responsibility, risks and rewards.

According to Mariotti (2002) a value network is "an interactive combination of information, machines and people". Value networks create value at each node. In this, we come across how input is transformed into output at different stages and value gets added at each stage. It is important to note that all players in respective nodes must have normal costs that are comparable to the average or better than average of the industry and ensure they charge only a normal and fair return as they move to the next node in the supply chain network. Such a practice leads to formation of a 
synchronized supply chain network for sustainable competitive advantage.

We can relate this with conscious competition. Conscious or value driven business takes into consideration the needs of consumers, vendors, shareholders and employees. Conscious competitiveness is a business approach of competing in the market by providing extraordinary value to the consumer and prioritizing his needs before other factors of the business, say, profitability etc. Conscious competitiveness strongly relate to factors like corporate social responsibility, sustainability and value addition in businesses that balance financial performance with preservation of the social good, conscious consumerism, responsible procurement process and socially responsible investment.

While supply chain defines transparency and objectivity to role agents, their responsibility and rewards, conscious competition extends the horizon to society who is a tacit player in business.

In this article, the authors have looked into how value networks in a traditional business like sugar industry in India where network operate is backwardly integrated. The network survives because of conscious competition and strategic alignment of firms taking leadership in evolving the industry. Unlike a competitive and free market forces operating in an industry where there is a larger scope for strategists to deploy interventions for better value creation across the network, in a regulated and large supplier participating in its economy it becomes complex. A sense of consciousness is more to be trigger and instilled across the network partners for survival of the system.

\section{Problem Statement}

1. Many times, value creation and appropriation are not synchronized as the intervening players are seemingly carrying divergent objectives. In such a case, value networks may be difficult to sustain.

2. Linkages are natural either because of autonomous systems' decision making or due to emergent strategies pursued by the focal firm. A focal firm is one around which the entire network is built. In the context of supply chain network, it is manufacturer or service provider to the customer and other nodes are linked towards the purpose of creating value to the customer. It is important to note here that whether it is natural / autonomous creation of the value network or created through an emergent strategic intent, a value network has to survive on merits of business proposition. Those which are created through emergent strategies are obviously had to be market driven. There are certain instances where in specific industries network creation is driven by regulations, limited resource deployment and the need to make group decision rather than independent economic decisions. These are what we call forced or compulsive value networks that are fragile and open to exploitation.

In this paper, we will discuss an industry where value networks are natural and autonomous. There is need to emphasize even in such a business there is need to ensure that the players in the value network have reasonable pay offs that justifies their survival and growth. In India sugar is one such industry that has been regulated over long years on price and distribution, licensing and so on. The design and implementation of policies ensure that creation of value network and autonomous survival of firms and vertical quasi integration of ownership is near impossible because of certain land measures implemented in the early 1970 s.

\section{Study Objectives}

1. To relate regulatory framework and structure of sugar of industry in India

2. To map the supply chain / value network of manufacture of sugar and its byproducts

3. To understand value network through financial performance of the industry and study whether focal firms are able to achieve reasonable return.

\section{Research Design and Methods}

This study is primarily an exploratory study on "Value Networks and Conscious Competition" where authors have looked into available literature for clarity on application of concept of value network along with other commonly used nomenclature in explaining supply network or business ecosystem. The nature of the industry is characterized by diverse interest groups working with complex network of relationships. Thus, by choosing an exploratory research as the design for conceptual understanding, authors wanted to validate the implications of value network and conscious competition in an industry which was operating under varying degree of regulatory management over years and now tending towards market driven industry. Using industry level published data from authentic sources; authors here applied analytical framework method for inferring rationale of Value network and conscious competition at an industry level. This has 
greater scope for being applied in similar industry analysis framework across regions and industries.

\section{Literature Review}

\subsection{Value Creation and appropriation}

The purpose of any business enterprise from single firm's point of view is to create value. Firms have recognized the need for building networks that leverage resources not owned by a firm; in order to create sustainable competitive advantage. Value appropriation is important for firm's growth and survival. Though value creation and value appropriation process is interlinked, many times both are not synchronized as the intervening players have seemingly divergent objectives. Before defining frame work for value creation and appropriation one needs to understand changing business models, industry characteristics, and firm's relationships with other network members across value network.

\subsection{Changing Business Models:}

Businesses, especially in traditional industries were self - reliant and inward looking with growth either through forward or backward integration. Firms believed in investing and creating their own assets. Size, volumes and scales of geographic distribution were the parameters that determined the strength of an organization in the market place. Today businesses are increasingly challenged by one or more of the following situations: saturation in the markets, breakthroughs in technology that shake up the status quo, cheaper and better alternatives and demand for value addition from the members of the value chain. This has necessitated revisiting the existing business models. The internet and developments in the field of information and communication technologies (ICTs) have made it possible to develop and operate systems that are transparent and seamless. Firms have redefined boundaries by making alliances with those players outside of their industry taking advantage of "open" /public assets like the internet. Businesses are also evolving to be more creative, flexible and creating new knowledge and expertise to create and deliver new products and services. Heterogeneous industries are increasingly converging for new product creation and service delivery. Such aggregation of new business models and blurring of boundaries across industries have led to emergence of new revenue models.

Traditional businesses also have compulsions of creating networks for value creation and sustain competition. For example, power engineering company which is in the business of manufacturing power equipment like pressure boilers and turbine can compete only if it creates a seamless supply chain where suppliers and ancillary units along with auxiliary equipment manufacturers form a value network. These firms also need to work on changing business model where they may have to involve partners from bidding stage to do concurrent engineering. Trust and ability to forge alliance relationship is what can reduce lead time and cost for achieving competitiveness.

While competition was the key element, collaboration, co-operation and co-evolution were discussed as important factors for building long term strategies for businesses. The term co-opetition introduced by Brandernburger and Nalebuff (1996) is based on the concept of applying a variant of game theory to strategic issues. According to them, a successful business strategy involves a 'value net' approach that comprises not only competitors but also the customers, suppliers and complementary firms of its business. To quote them, "Co-opetition recognizes that business relationships have more than one aspect. As a result, it can occasionally sound paradoxical. But this is part of what makes co-opetition such a powerful mindset. It's optimistic, without being naive. It encourages bold action, while helping you to escape the pitfalls. It encourages a firm to adopt a benevolent attitude towards other players, while at the same time keeping the firm toughminded and logical. By showing the way to new opportunities, co-opetition stimulates creativity". Porter in his cluster theory has articulated how horizontally and vertically firms are able cooperate among competing firms and also with network partners like suppliers and distributors in a geographical cluster for achieving economic growth. Ancarani and Shankar (2003) also reveal similar phenomena in convergent industries. According to them, the emergence of new forms of hybrid competition that include competition and cooperation drive the need for the right strategic alliances in convergent industries. The strategic ability to setup and run value networks with partners like competing firms, supporting firms, suppliers and even customers is key to success in convergent industries. The focus of strategic management must be network of firms and not resource based view or any other structural view. They further state that managers face two key strategic challenges when competing in convergent industries: 1 maintaining focus on customer relationships; and 2. Identifying partners for strategic alliances and managing the alliances, often collaborating with competitors in traditional industries. Though the above inference especially towards customer relationships could be true for market driven industries, it is important to note there are other set of traditional industries which may also have to modified with broader social perspective in a resource based regulated industries. This would be focused in this paper. It may be noted here 
that business ecosystem models and network models are modular forms that are developed from collaborative theories.

\subsection{Ecosystem model}

Business ecosystems derive their meaning and essence from ecosystems existing in nature. An ecosystem is a place that has numerous living things in perfect balance. Business ecosystems gained acceptance and popularity after it was first proposed by James F. Moore (1993). The concept of ecosystem replaces competition with co-evolution, wherein stakeholders, potential competitors and governmental institutions work together to create a better future for all the members of the ecosystem. James F Moore (1996 \& 2006) suggests that the core of a business ecosystem consists of core products, complementary products, leading firms, complementing firms, competitors, customers and suppliers interacting with each other. Brandenburger and Nalebuff (1996) have proposed a similar thought in terms of 'value net'. Business ecosystems have been described as "meta-markets", "virtual clusters" and as "C-Commerce". Other terms that are used to describe the overlapping meanings of business ecosystems are co-opetition, value net and value constellation.

\subsection{Network Models}

Literature on network theory is replete with comprehensive reviews of networks and their governance. Network models illustrate a wide array of relationships ranging from the dyadic and simple relationship between the buyer and seller to complex networks. Strategic alliances involving relationship between two firms to derive mutual benefit in one or more business functions gained importance. An alliance may be seen as the 'joining of forces and resources, for a specified or indefinite period, to achieve a common objective'. NTT DOCOMO, INC. (DOCOMO) and Tata Teleservices Limited (TTSL) are in a strategic alliance, to expand mobile communication operations in the fast-growing Indian mobile market. Star Alliance among many airline operators is another classic example which has been operating successfully over decades. Strategic alliance is the name given to a form of corporate structure in which a number of organizations link together, usually by taking small stakes in each other and as a result of having a close business relationship, often as suppliers to each other.

The network structure is a way to defuse the traditionally adversarial relationship between buyers and suppliers. Chrysler adopted the keiretsu model resulting in the company's relationship with its suppliers, reducing in number from 2,500 in 1989 to 1,140 in 1996, and improving of relationships between the firms to such an extent, that Dyer claimed "the two sides now strive together to find ways to lower the costs of making cars and to share the savings" (Dyer, 1996).

Here, one may relate network to supply chain. Success of each firm in the value chain depended not only on its own performance but also on the strength of the linkage and the interaction between all the firms in the chain. Competition then shifted from inter-firm to inter - value networks. The result was that strategic alliances were not confined to just two firms but went on to include more firms.

Network organization followed supply chain management thinking. Several authors observed that a variety of industries created their own networks. And network governance coordination was largely by informal social systems rather than formal, bureaucratic structures within firms and formal contractual arrangements between firms to coordinate complex products or services in unpredictable and competitive environments (Piore and Sabel, 1984; Powell, 1990; Ring and Van de Van, 1992; Miles, Snow, and Coleman, 1992). Network governance involves a select, persistent, and structured set of autonomous firms as well as not-for-profit agencies engaged in creating products or services based on implicit and open-ended contracts to adapt to environmental contingencies and to coordinate and safeguard exchanges (Jones et.al 1997). Network organizations have been observed globally in a variety of industries including semiconductors, biotechnology, film music, financial services, courier services, fashion designing and even in the field of education.

While individual firms compete and bargain for more space, the emphasis is on the overall well-being of the ecosystem. Prahalad and Hamel (1990) advocated the exploitation of core competencies, later models emphasized value creation through 'share of the customer' approach by putting together several competencies to address the needs of the customer.

According to Mariotti (2002) a value network is "an interactive combination of information, machines and people". Value networks are concentrated in creating value in each node. Value network is not seen as bound to certain region - it can even be global. The concept of industry is included in the discussion of value network, but companies inside a Value network can be parts of different industries. Value network and business ecosystem are not based on geographic aspects. It is a co-operative structure. The members' tasks are strictly defined and generally not expected to compete 
with other members. The whole idea of value network arises from a notion that a single firm cannot produce the whole product by itself and needs other firms with different capabilities to complement the product.

Having discussed about ecosystem, supply network and value network and how firms can align to create value for customers and share appropriately, it could be important to understand on failure of ecosystem or value networks.

Differences in perception, inability to communicate the benefits to the network partners, network partners' fear of cannibalization, failure to innovate, market myopia towards innovations and inability to reach higher scale of operation are likely factors for failure.

The peculiarity of Indian ecosystems is that a number of participants in the ecosystem are from the unorganized sector and are not governed by regulations. However these members get to engage with formal, organized segments such as corporations and associations, thereby creating unique ecosystems. They get to be mentored by formal corporations and trade associations. Predominance of players from the organized sector in creation of social capital and appropriate mentoring for partners are important to avoid bias in value distribution.

A company looking to build an ecosystem needs to focus on its own core competencies because these elements are what make the company attractive to other potential members of an ecosystem. In the business ecosystem, relationships are interdependent and a firm can benefit from it without being a leader. Great partners are more conducive than many partners. The relationships between members of an ecosystem are rarely one - on - one. As in diplomacy, a firm in an ecosystem needs to consider how its dealings with one partner might affect others within its group. Here unity gives considerable strength.

The network phenomenon is in four ways as internal, vertical, inter market and opportunity network. In a knowledge society with dynamic industries, the task is to create organizations that are maximally open to the environment and can seek a state of more or less continuous adaptation to the non-static environment. These knowledge firms have weak hierarchies, dense lateral connections, low departmental walls and openness to environment. In the case of vertical network model, the focal organization does the 'integrator' role and manufactures only a few components. Nike and Cisco follow this model and energy is rather diverted to coordination and customer relationship. The third one inter market synergy aims to have business that can help each other and benefit.

In the present business environment, firms are endeavoring to discover ways to survive, compete and succeed in their businesses. The value chain concept (Porter, 1980; Porter, 1985) that has been used for over three decades to understand and analyze industries is less applicable now thanks to the loosening of the linkages along the value chain and products and services becoming highly dematerialized (Normann and Ramirez, 1994; Parolini, 1999; Hakansson and Snehota, 1989; Campbell and Wilson, 1996). This phenomenon has been noted in a variety of sectors such as banking, insurance, telecommunications, new entertainment, music, advertising and certain areas of the public sector ( $\mathrm{Li}$ and Whalley, 2002; Evans and Wurster, 2000). Blurred physical dimensions of the value chain have paved the way for cooperative behaviour and inter-firm associations have become critical in strategy formulation (Madhavan et al., 1998). Adoption of a network perspective is the alternative to value chain in the current model of business, particularly for those organizations where both the product and supply and demand chain is digitized (Peppard and Rylander, 2006). In the network approach, while the firms in the network are independent, the focus is not on the company or the industry but the value-creating system itself, within which different economic actors - supplier's partners, allies, and customers - work together to co-produce value. Success of a network depends on proper definition of role, responsibility, risk and reward among participants which is being well articulated and executed by the focal firm.

However, business ecosystem is an emerging concept for strategic decision making. Formation of cooperatives as in the case of AMUL and Campco are illustrations of ecosystem creation. The strong interlinkage of the players in an ecosystem compels the survival of each firm to be coupled with that of the overall business ecosystem. Cooperative movement in India has a long standing contribution in the growth of business and agriculture. Besides, the cooperative approach has also seen success in natural resource management. It is observed in agricultural resources that include agricultural product, milk and milk products, fisheries, and horticultural products that cooperative system plays a crucial role in the production and marketing which in turn support a large number of families engaged in the production of these. A success in marketing of these products percolates to enhanced production and hence income of the families engaged in the production process. A successful cooperative system (especially in these products) require a winning combination of financing, marketing strategy and most importantly an institutional structure that enables large participation of the producers on a sustainable basis. There are ample examples of successful cooperative systems available in Indian context including the well-known AMUL movement of Gujarat in milk production. Besides, one can also observe instances of success in sugar cooperatives, fisheries etc. Yet another popular cooperative movement in India is the Central Areca nut and Cocoa Marketing and Processing Co-operative Limited (CAMPCO).

To summarize, there are number of works which supports value network, supply chain network and business 
ecosystem that a focal firm while creating value to customers anchors the network along with partners with clear objectives and governance mechanism. Else, systems may have natural limitations and realignment could happen. However, we feel that there could be considerations in traditional industries where a network could be aligned more because non-market factors and other tacit support which neutralizes the economic disadvantage in the system.

\section{Analysis}

\subsection{Structure of the industry and Regulatory}

Structure of the industry relates to the framework or organization of industry forces which includes mainly producers, consumers, regulatory and other players in the business ecosystem who collectively influence the industry in terms of its competitive behavior and performance. Some of the structural features are analyzed below:

i. India is one of the largest consumers of sugar in the world. India consumes around 22.8 million tonnes of sugar as of 2013. Per capita sugar consumption is about 19 kilo compared to the global per capita of 24 kilo. It may be noted here that large part of consumption is by bulk consumers. This would include: food industry which is largely dominated by unorganized sector and in organized sector by beverage and pharmaceuticals industry. At an estimated 4 per cent compound annual growth rate in consumption, demand for sugar in India is expected to be around 30 - 31 million tonnes by 2020 (ISMA). Clearly, demand is firm and stable. It may also be noted here that the demand of sugar is politically sensitive as calories demand of low income group in India is met by sugar consumption.

ii. After having discussed demand, structure of the industry depends upon supply conditions as well. Supply is domestic production and net of foreign trade. It may be observed from the table 1 that the sugar production which was 20.1 million tons in 2002-03 touched a low of 12.7 million tons in 2004-05 but peaked at 28.4 million tons on 2006-07. It was around 25 million tons by 2012-13.

Table 1: Sugar: Production, Trade and Net Availability in India

(Million tons)

\begin{tabular}{|c|c|c|c|c|}
\hline Year & Production & Imports & Exports & Availability \\
\hline $2002-03$ & 20.1 & 0.1 & 1.8 & 18.4 \\
\hline $2003-04$ & 13.5 & 0.6 & 0.3 & 13.8 \\
\hline $2004-05$ & 12.7 & 2.1 & 0 & 14.8 \\
\hline $2005-06$ & 19.3 & & 1.1 & 18.2 \\
\hline $2006-07$ & 28.4 & & 1.7 & 26.7 \\
\hline $2007-08$ & 26.4 & & 5.0 & 21.4 \\
\hline $2008-09$ & 14.5 & 2.4 & 0.2 & 16.7 \\
\hline $2009-10$ & 18.9 & 4.1 & 0.2 & 22.8 \\
\hline $2010-11$ & 24.4 & & 2.6 & 21.8 \\
\hline $2011-12$ & 26.3 & & 3.4 & 22.9 \\
\hline $2012-13$ & 25.1 & & 0.35 & 24.75 \\
\hline $2013-14$ (Est.) & 25.0 & & & 25.0 \\
\hline Std.dev & 5.49 & & & 4.17 \\
\hline Coefft.Var & 25.87 & & & 20.26 \\
\hline
\end{tabular}

Source: ISMA November 2013

Production is volatile and trade to some extent tries to support local availability. It may be noted that the volatility is high as seen from standard deviation and coefficient of variation data given in the table. The government has been managing through release management by controlling releases and stock help to balance shortfall in production. However, with release regulation being withdrawn it is going to be onus on the industry to allow market forces to manage the same. Such volatility will have an impact on firm performance as well as on managing supplier relationship by way of payment to cane farmers. This further gets complicated with central and state government intervening on cane price fixation to protect farming community. Thus, a constituent of supply network gets a supposedly "preferential" treatment to protect the industry. Before exploring further on balancing of supply network, let us discuss a few other parameters which affect sugar production. 
There are three parameters namely sugar recovery from cane, cane yield per hectare of land and competitive use of cane for manufacture of sweeteners like sugar, Gur and Khandsari in India.

On sugar recovery, it may be observed that on average on All India basis, sugar recovery is around 10 per cent as of 2012-13. It was at a peak of 10.6 per cent 2007-08. The lowest ever in the last 32 years is about 9.4 per cent in 199596. However, it may be noted that every 0.1 per cent is significant in challenging the supply conditions. Further, though we consider that it has stabilized at around 10.2 per cent in India, there is a wide fluctuations across regions and even within East and West Uttar Pradesh. We may classify into two zones as high recovery and low recovery regions and variation around one per cent. Though cane price is linked to recovery, it is not a balancing factor rather a tool for incentives which by design challenges supply network. This is mainly because of agro climatic conditions which facilitate ideal recovery between January to March whereas average would be stretched because of better cane pricing during a previous year deficit. Thus, recovery in India affects supply network and focal firms namely sugar companies are at a disadvantage.

Cane yield per hectare in India has been on an average around 70 tons (Table 2). This has been almost stabilized with occasional drop by about 7 to 8 per cent on a long cycle, say 10 years. The concern is with productivity being limited farmers could meet growing demand for income only from sugarcane price increases. Further, cane availability is going to be a limiting factor in years ahead. From supply network perspective, farmers' land being available and increasingly made productive is what could be critical. Land productivity increase is a significant challenge in India.

On availability of cane for manufacture of sugar, about 65 per cent is used for the same. Gur takes over 20 per cent and 12 per cent goes for seed cane. It is important to note here any additional cane for manufacture for sugar cane comes manufacture of gur but unlikely as coefficient of variation for both sugar and gur is similar. Moreover, gur is consumed by low income and below poverty line consumers as it is a low priced substitute for sugar. Hence, cane availability for sugar would be challenging and dramatic change is unlikely to happen.

Table 2: Utilization of cane for manufacture of sugar and its substitutes

\begin{tabular}{|c|c|c|c|c|c|c|c|}
\hline & & & & \multicolumn{4}{|c|}{ Cane for production of } \\
\hline Year & Area & Yield & Production & Sugar & Khandsari & Gur & Seed \\
\hline & Mha & MT/ha & MMT & MMT & MMT & MMT & MMT \\
\hline $2000-01$ & 4.32 & 69.35 & 299.32 & 176.65 & 11.00 & 75.75 & 35.92 \\
\hline $2001-02$ & 4.41 & 67.09 & 295.95 & 180.32 & 10.50 & 69.62 & 35.51 \\
\hline $2002-03$ & 4.52 & 63.58 & 287.38 & 194.33 & 9.50 & 49.07 & 34.49 \\
\hline $2003-04$ & 3.94 & 59.39 & 233.86 & 132.51 & 10.00 & 63.29 & 28.06 \\
\hline $2004-05$ & 3.66 & 64.74 & 237.08 & 124.77 & 9.50 & 74.36 & 28.45 \\
\hline $2005-06$ & 4.20 & 66.93 & 281.17 & 188.67 & 8.50 & 50.26 & 33.74 \\
\hline $2006-07$ & 5.15 & 69.03 & 355.52 & 222.00 & 10.00 & 80.86 & 42.66 \\
\hline $2007-08$ & 5.06 & 68.81 & 348.18 & 249.91 & 7.00 & 49.49 & 41.78 \\
\hline $2008-09$ & 4.44 & 64.19 & 285.02 & 145.00 & 6.50 & 99.32 & 34.20 \\
\hline $2009-10$ & 4.18 & 70.01 & 292.30 & 185.55 & 6.50 & 65.17 & 35.08 \\
\hline $2010-11$ & 4.89 & 70.09 & 342.38 & 240.00 & 7.50 & 53.79 & 41.09 \\
\hline $2011-12$ & 5.04 & 71.66 & 361.03 & 257.00 & 7.00 & 53.70 & 43.32 \\
\hline $2012-13$ & 5.06 & 67.38 & 341.20 & 251.50 & 7.00 & 41.75 & 40.94 \\
\hline $2013-14$ & 5.12 & 67.74 & 346.81 & 242.00 & 8.00 & 55.19 & 41.62 \\
\hline $2014-15$ & 5.03 & 69.80 & 350.81 & 245.43 & 6.50 & 56.78 & 42.10 \\
\hline Average & 4.60 & 67.32 & 310.53 & 202.38 & 8.33 & 62.56 & 37.26 \\
\hline Std.dev & 0.48 & 3.19 & 42.15 & 45.32 & 1.61 & 15.21 & 5.06 \\
\hline CV & 10.5 & 4.7 & 13.6 & 22.4 & 19.3 & 24.3 & 13.6 \\
\hline
\end{tabular}

Source: CRISIL Research, 2014

Thus, the upstream linkages of supply network in sugar industry are quite challenging. Whether it is regulated or some of the challenges are more because of the nature of demand and supply side factors. These challenges are likely to continue.

iii. On regulatory aspects, the industry had been under price and distribution control on the downstream side of supply network and on the upstream, it had controls on minimum cane price to be paid to farmers and location through licensing and minimum distance criteria between two factories. Till April 2013, sugar sales were controlled by levy sugar 
to be sold below market price, release mechanism for sale on monthly basis, control on exports and imports and need to pack in jute bags. Post April 2013, levy sugar and release mechanism have been done away with. This would link downstream with market forces. Further changes in downstream include removal of quantity and time based export import control and limiting it to tariff policy and reducing jute bags mandatory bagging to 40 per cent of output. Though the recommendation by expert committee (Rangarajan) included: dispensing with "minimum distance criteria", removal of controls on molasses, easing out surplus power selling to grid and complete removal of need to pack in jute bags.

Said these, regulatory framework has led to fragmentation of the industry. The sugar manufacturer who is the focal firm in the supply network was more saddled with managing the network through regulatory rather than market forces.

iv. There are more than 600 factories. It may be noted that most of the plants in India are of 2500 tons of cane crushed in a day (tcd). Over the years, some of the factories increased the capacity to 5000 tcd of size. This required additional land to be allotted in the command area and both central and state governments to give approvals for various aspects. More importantly, many firms sought to get a new license rather than adding capacity and increasing normal size. This is mainly because new license gave more quota to be sold in open market. Thus, policy framework limited the supply network by reducing normal size to 2500 tcd and as on date average size in India is around 3750 tcd whereas the expert committee recommends optimal size for a sugar factory to be 5000 tcd. International standards are further high at 7500 tcd.

It may be further noted here how normal size could limit supply network synchronized flow of product, information and financial flows. A large size plant, say 5000 tcd facilitates for co-generation of power and better realization for cane procured. Efficiency improvements are aplenty. Thus, supply network constraint is further imposed on location and facility sizing along with scope for joint and by products.

Another structural perspective is that of ownership where Indian sugar industry is largely owned by farmer cooperative societies which are run by professional managers. There is a large agency problem due to owners and trustees priorities. Internal supply chain efficiencies are affected as many times decisions could be suboptimal because of conflicts between owners and professional managers. Thus, structural analysis of sugar industry in relation to its value network shows limitation on design, objectives and lack of role clarity impacting performance. To validate the same, we would map the supply chain as below and relate performance of the industry.

\subsection{Supply chain Network}

Based on the discussions above, we present the following supply / value network partners in sugar industry.

Key Node in the network: Firm manufacturing sugar referred to as thefocal firm.

Role: Focal firm who initiates and owns the value network

Responsibility: Manufacture sugar by procuring cane in the command area. Incidentally, joint products \& by products like power, bagasse, molasses \& Press mud and forward integration for industrial / potable alcohol.

Reward: Earn that rate of return on capital employed which compares with the market and attract further capital to create additional capacity to meet demand.

Risk: Business which consists of operating risk (measured by variability in EBITDA reflecting revenue or cost management), financial risk measured by debt - equity which is high because of stock to be held and portfolio risk of businesses run by the firm in terms of joint \& by products. A focal firm in this industry carries high operating and financial risk which is against normal practice in a market lead business.

Upstream Node in the network: Cane farmers supplying to the focal firm

Role: Supplier of cane to the factory as land located in demarcated area of development under the factory. Follows best practices as advised and supported by the focal firm.

Responsibility: Supply cane with a right to exercise choice to be part of the value network. Reward: Benefit competitive crop income with the support of firm in improving physical performance and get better realization of revenue with price fixed by the government and paid by the focal firm.

Risk: Business which consists of operating risk of focal firm not procuring cane on time especially during surplus cane production due to environmental factors, and financial risk measured by debt raised for cane production or mainly due to delayed payment of cane prices by the firm. A firm would not have paid as they got into a financial distress because of poor price realizations. However, downstream farmers face more of cash flow timing issue as cane price are politically influenced because of group bargaining power and at times their agricultural loans being waived as a policy decision. Though this works as an indirect subsidy in support of sugar consumers, private factory owners would not benefit out of this.

Downstream Node in the network: Dealers - Retailers - Consumers channel 
Role: Retail consumers who buy sugar of the focal firm which a dealer triggers the sale by connecting the firm and a local agent and then through to retailers. Physical flow management is till sugar reaches customers.

Responsibility: Dealer is mainly a broker who aggregates retail order and delivers after picking up from the factory. All the constituents here work for a margin. Customer looks for appropriate price at which he can buy a required quantity of sugar.

Reward: Fair price and adequate quantity to buy is what the customer expects. Since there was a regulated release mechanism and levy price, the consumers were insulated from volatility in price and availability. Now that the regulatory mechanism has been withdrawn, we may have to observe a couple of years to understand how it works. Theoretically, market forces must drive for better value, though consumers may end up paying a premium which was absorbed as cost of protection by the government.

Risk: In the regulated regime retail consumers were well protected. Sugar price in the price index grew at 3 per cent over a midterm period of five years whereas overall index had gone by 7 per cent and food articles price had much higher rise. However, one would expect that though once market forces have started operating since April 2013, prices have been stable, and one has observe outcome during deficit sugar year which is unlikely in the current year as well. As of now, consumers are enjoying low price risk. This is further to the fact that India is the consumption and supply centre. And if there is deficit in supply which could affect price, it can be supported by an import from Brazil. However, when international market senses deficit in India, price has a tendency to firm up. Thus, consumer market price risk is limited.

Downstream Node in the network: Direct supply to institutional buyers

Role: Institutional consumers like drug manufacturers, beverages and others who use large quantity of sugar as ingredient buy sugar of the focal firm directly on ex-factory basis .

Responsibility: Institutional buyers are the major node in supply network. Though in India, data breakup is not exactly available in open source, according to ISMA it could be around 65 per cent. But this would include institutional consumers who buy through dealers as well which are not part of direct channel. We would focus on direct channel buyers here who buy the same product as others.

Reward: Fair price is to be set as the reward. Till now, they buy as part of open quota and it is market based pricing. However, our view is that the pricing must be differentiated based on value creation as product application and value as intermediary is high. It is not appropriate that they benefit out of market imperfection. It may sound theoretical at this point but would set under free market conditions as sugar mills will also have compulsions in fulfilling their differentiated markets in open market condition in an economy when regulation is withdrawn. Since it is just about 18 months after withdrawal of distribution control, the carry over stock is available as a Cushion for balancing price. The real effect would be seen as we move on a full sugar cycle of lean and surplus seasons in a deregulated environment.

Risk: As mentioned above, price risk is the major key which would be more appropriately understood when full scale deregulation of distribution control is operational. As of now, institutional buyers are guided by market price based on largely dealer market conditions.

Impact of Support System node is as follows:

i. We discussed in detail about role of central government. It fixes the statutory minimum price (SMP) for cane. Since this is not linked to output price, it distorts the value / supply network. Neither market forces operate the industry nor do partners appreciate trust factor for long term survival and growth. It is important the transition initiated must settle for market forces and there would be some shake outs which must be tolerated for overall interest of the economy. This is more in tune with winds of change towards deregulation and business like orientation towards agriculture and on agro based industries.

ii. ii. State Governments play a major role especially in sugarcane dominant states as political stakes are high. This gets complicated with populist approach of regional parties and because of coalition politics fueling state governments' such ambitions. State government must avoid intervening and should only be a facilitator. The original idea of State Advised Price (SAP) was a role of facilitator in adjusting SMP to more realistic towards local conditions like yield and competitive cropping. This must be allowed for the market forces to decide.

iii. Firms which have set up cogeneration of power are able to export. Policy need to be consistent across states and pricing must be fair. More importantly, because of inefficiencies of some of the electricity boards payments are being delayed which again hurts the industry. From value network perspective, joint product has a poor value network system which impinges the main industry namely sugar.

Thus, in the value network, firms operate for earning market returns on their investment. Cane farmers as vendors are protected by minimum price policy but suffer on cash flows because of poor financial viability of mills and till recently output price was guided by open market conditions. Each node has conflicting objectives. It leads to interesting question on understanding the industry financial performance over the years. If the focal firm is not earning a market return, 
business ecosystem may be fragile and realignment would happen as other participants in the system would suffer either receiving low return or mismanaged as flow timing.

\subsection{Financial Performance of Sugar Industry:}

It can be observed from the table 3 that the industry earns a poor net margin and return on capital employed which is on average less than 5 per cent. Drop in production and stock use ratio as can be observed from macro data is what helping the industry to earn a high return. For example, when stock to use came down to 11 per cent and product nearly dropped by 45 per cent in the year 2008-09, performance looked attractive. But that was not sustainable as raw material cost as percentage of sales went up significantly and sustained at that level. Thus, increase in cane price and poor market realization for output price as can be seen from sugar price data makes the value/supply network less synchronized. It may further be noted that creditors' days are higher showing inability to pay on time. Further, finished goods inventory days are as high as 146 days and on an average about 120 days which highlights pressure to carry stocks. All such parameters would affect financial performance and increases business risk. If such burden can be shared proportionately across the chain, then one could appreciate synchronized network being in operation.

Table 3: Sugar Industry financials and macro data

\begin{tabular}{|l|l|c|c|c|c|c|c|}
\hline \hline & \multicolumn{1}{|c|}{ Unit } & $2007-08$ & $2008-09$ & $2009-10$ & $2010-11$ & $20011-12$ & $2012-13$ \\
\hline Operating profit margin & Per cent & 14 & 20.2 & 14.1 & 11.6 & 11.2 & 12.5 \\
\hline Net profit margin & Per cent & -0.1 & 11.4 & 3.4 & 0.2 & -0.9 & 1.4 \\
\hline Return on capital employed & Per cent & 5.5 & 14.9 & 7.5 & 6.7 & 5.5 & 8.1 \\
\hline Interest coverage ratio & times & 1.6 & 3.4 & 2.5 & 1.6 & 1.4 & 1.8 \\
\hline Debt equity ratio & times & 2.3 & 1.5 & 1.9 & 2 & 2 & 2 \\
\hline Current ratio & times & 2.2 & 2.3 & 2.3 & 3 & 3.2 & 2.9 \\
\hline Finished goods & days & 120 & 104 & 121 & 109 & 126 & 146 \\
\hline Debtor days & days & 23 & 21 & 21 & 22 & 29 & 26 \\
\hline Creditors days & days & 119 & 138 & 138 & 64 & 81 & 100 \\
\hline Raw material cost as \% of sales & Per cent & 67.7 & 63.6 & 72 & 75.4 & 75.8 & 74.3 \\
\hline \hline Macro data: & & & & & & & \\
\hline Average sugar price & Rs. Per tonne & 15,142 & 22,787 & 30,774 & 28,107 & 30,848 & 32,420 \\
\hline Sugar production & million tonnes & 26.4 & 14.5 & 18.9 & 24.5 & 26.2 & 24.8 \\
\hline Sugar consumption & million tonnes & 22 & 23 & 21 & 22.1 & 22.9 & 23.7 \\
\hline Exports & million tonnes & 5 & 0.2 & 0.2 & 2.7 & 3.2 & 0 \\
\hline Imports & million tonnes & 0 & 2.5 & 4.2 & 0 & 0 & 0.3 \\
\hline Closing stock & million tonnes & 8.6 & 2.5 & 4.4 & 4.2 & 4.3 & 5.7 \\
\hline Stock-to-use ratio & per cent & 32 & 11 & 21 & 17 & 16 & 24 \\
\hline
\end{tabular}

Source: CRISIL, Oct, 2013.

\section{Conclusion}

It is observed from this paper that supply / value network across sugar industry is poorly structured because of divergent goals across the chain and inability of the focal firms to manage and control node agents. Buyers and suppliers' bargaining power supported by regulatory framework have eroded value creation of the industry. Often, the ecosystem participants are wrapped up in conflict and litigation because the regulations are neither consistent nor market centric. Industry needs to be market oriented. Location and size inefficiencies will have to go as normal size must move up to 5000 tcd and above. Also, joint and by products must be allowed to be managed better so that value realization is improved and cross subsidization must help reduce business risk instead of increasing it. That would incentivize firms to restructure and make inorganic moves for the benefit of the industry. The government must think radically, perhaps, even allowing asset restructuring of cooperatives and improving governance whereby they can partner with others to bring in private capital. This industry like many traditional ones, have supply networks operating rather inefficiently and choking because of write-offs and subsidies instead of improving market efficiencies. All stakeholders must appreciate the role of focal firm in running its business and eco system must facilitate the same. 


\section{References}

Christopher, Martin, Logistics and Supply Chain Management: Strategies for Reducing Cost and Improving Service, 2nd edition. Great Britain: Financial Times / Prentice Hall, 1998.

Mariotti, J.L., "The Value Network", in Executive Excellence, Vol. 19, No. 7, 2002.

Moore, James F., Predators and Prey: A New Ecology of Competition, Harvard Business Review. May-June 1993.

Moore, James F., The Death of Competition. Leadership and Strategy in the Age of Business Ecosystems. John Wiley \& Sons Ltd, West Sussex., 1996.

Moore, James F. , Business Ecosystems and the View From the Firm. The Antitrust Bulletin, 51 (1), 2006.

Brandenburger, A. and Nalebuff, B., Co-opetition. Published by Broadway Business, New York, 1996.

Dyer, J.H., "How Chrysler Created an American Keiretsu", Harvard Business Review, July-August 1996

Piore, Michael J. and Charles F.Sabel, The Second Industrial Divide: Possibilities for Prosperity. New York, Basic Books. 1984;

Powell Walter W, Neither Market nor Hierarchy: Network forms of Organization, Research in Organizational Behavior, Vol.12, 1990

Ring, Peter Smith and Van de Ven, Andrew H, Structuring cooperative relationships between organizations, Strategic Management Journal, Volume 13, Issue 7, October 1992

Miles, C. C., Snow, R. E., and Coleman, H. J., Jr., Managing 21st century network organizations. Organizational Dynamics 20(3): 1992.

Jones, C., Hesterly, W. S., \& Borgatti, S. P., A general theory of network governance: Exchange conditions and social mechanisms. Academy of Management Review, 22(4), 1997.

C.K, Prahalad and Gary Hamel., The Core competence of the corporation, Harvard Business Review, May-June 1990.

Porter, M.E., Competitive Strategy, Free Press, New York, 1980

Porter, M.E. , Competitive Advantage, Free Press, New York, 1985

Normann, R. \& Ramirez, R., Designing Interactive Strategy: From Value Chain to Value Constellation. Chichester: John Wiley \& Sons. 1994.

Parolini, C., The Value Net: A Tool for Competitive Strategy. Chichester: Wiley, 1999.

Hakansson, H. \& Snehota, I, "No Business is an Island: The Network Concept of Business Strategy", Scandinavian Journal of Management, Vol 4, No. 3, 1989.

Campbell, A.J. and Wilson, D., "Managed networks: creating strategic advantage", in

lacobucci, D. (Ed.), Networks in Marketing, Sage, London, 1996

$\mathrm{Li}$, F. in Whalley, J., Deconstruction of the telecommunicatons industry: from value chains to value networks, Telecommunications Policy 26, 2002.

Evans P and Wurster T S, Blown to Bits: how the new economics of information transforms strategy, Harvard Business School Press, Boston, USA, 2000.

Madhavan, R., Koka, B.R. and Prescott, J.E. , "Networks in transition: how industry events (re)shape interfirm relationships", Strategic Management Journal, Vol. 19 No. 5, 1998.

Peppard J. and Rylander, A., From Value Chain to Value Network: Insights for Mobile Operators, European Management Journal, 24 (23), 2006.

Presentation made by Abinash Verma, Dirctor-General, Indian Sugar Mill Association, at ISO - London on November, 25, 2013.

CRISIL Research, Return on Capital Employed for sugar industry, October 312013.

CRISIL Research, Sugar Industry Report, 2014. 